\title{
FROM DIALECT TO ETHNIC IDENTITY: THE CHINESE COMMUNITY IN THE KLANG VALLEY AS A CASE STUDY
}

\author{
Wen Wei* \\ Danny Wong Tze-Ken** \\ University of Malaya (UM)
}

\begin{abstract}
This article reviews the history of the Hakka, Cantonese and Hokkien dialect groups who had successively become the leading forces among the Chinese in the Klang Valley from 1860 prior to the World War II. It also examines rivalries between different dialect groups which were related to the Chinese community leadership in four aspects covered by the position of Kapitan Cina; the management rights in Chinese temples and ancestral halls; the bloody riots and the presidentship in the Chinese economic and social bodies like the Selangor Chinese Chamber of Commerce and the Selangor Chinese Assembly Hall. The objectives of this article are to identify two dialect groups power transformations within the Chinese community and to analyze the factors which resulted to these dialect power shifts and the Chinese ethnic integration. The analyses in this article are based on the primary sources consisting of the files of Colonial Office from the National Archives, London, Selangor Annual Reports from the National Archives of Malaysia, the secondary sources consisting of the magazines from different Chinese associations in Selangor and Kuala Lumpur, Chinese newspapers which preserved in Singapore and some Chinese Foreign Ministry records from Academia Historica, Taiwan. This study found that the Hakka power was based on its authoritarian leadership, the Cantonese power was based on their economic strength and the Hokkien power was based on their abilities to stimulate the Chinese ethnic integration.
\end{abstract}

Keywords: Dialect groups, Klang Valley, Dialect identity, Chinese ethnicity.

\section{Introduction}

Chinese community in the Klang Valley region before the World War II consisted of different dialect groups. The earliest Chinese immigrants in the Straits Settlements were the Hokkiens, who were involved in various profitable industries like shipping, trading and woodworks. Mak Lau Fong in his study, observed and analyzed the dialectal transformation situations which took place in the three states in the Straits Settlements of Peninsula Malaya - Malacca, Penang and Singapore. Of all these areas had had strong secret society influence; the Hokkiens had always played the leading role in the most influential secret society- the Ghee Hin which might had been a major contributor in maintaining the Hokkien dialect in the Hokkien leadership of the Chinese communities from the early $19^{\text {th }}$ Century until the day of writing (1981) in these three states.

Having said that, it is significant to acknowledge that in the other areas of the peninsula, like the Klang Valley and the Kinta Valley, the situation was different. These two areas had been mainly developed by the earliest Chinese immigrants to that particular areas-which were the main tin mining districts in the peninsula. The Hakkas were the dialect group that was brought from the mainland to work the tin mines. In this research, Kinta valley area is omitted as the Hakka dialect as a dominant dialect has not undergone any change from 1870 s to 1950 s. ${ }^{1}$ The Chinese communities were 
controlled by the Hai San gang who did not allow other dialect groups to operate in their business territories.

In the Klang Valley, however, the pattern of dominant dialectal power underwent changes through the six decades from 1880s to 1940s. Since 1844, the earliest and largest group of Chinese that came were the Hakka laborers who were intended to work in tin mines in the Klang Valley owned either by the Malays or the British and later on by their own Chinese miners².

After the Hakkas, the Cantonese and Hokkien members also gravitated from the Larut region in Perak and the Lukut region in Negeri Sembilan towards the Klang Valley decades later. Unlike the Hokkien groups in the Straits Settlements, where leadership among the local Chinese communities was controlled and maintained by the secret society, the situation in the Klang Valley region was totally different. The power of the secret society was eroded, and its relevance was taken away by the establishment of the Chinese Protectorate Office and Po Leung Kok (protector of female and young children) under the British administration in 1900 and 1901. This situation contributed to the rise of Cantonese influence in the Klang Valley.

From 1901 to 1930s, the Cantonese became economically superior within the Klang Valley's Chinese community. However, their leadership patterns were different compared to that of the Hokkiens in the Straits Settlements. The Hokkien leadership pattern was one which was partially similar to that of the Hakkas, in that both of them were very dependent on the power and influence of their secret society gangs. Benefits from secret society influence did not cover the Cantonese in the Klang Valley who were empowered instead by their capital resources and the British administration behind them.

Most scholars focused their studies on the different aspects of developments of the Chinese migrants in the Kinta Valley region in Perak and the Klang Valley in Selangor, two major tin mining areas of the Malay Peninsula which can be classified as the impetus to the growth of the Malaysian economy. While a lot of researches have been done on the changes in the Chinese communities in these areas, they mainly focused on individual leadership patterns rather than from the aspect of dialectal influence and the part it has played in the history of Chinese community development and the changes that were brought about by certain dialect groups to groom them into the Chinese ethnicity in a foreign land. The process of dialectal transformation throughout the six decades in the Klang Valley led to power shifts between the different dialect groups and finally neutralized all power considerations in the face of adversities to build a common ethnicity. This fairly untouched and interesting phase of transformation of the Chinese community in the Klang Valley is the crux and basis of my research.

There are 3 major waves of Chinese migration into the Klang Valley which are identified:

1. During the 2 decades between the Selangor Civil Wars (1862-1867, 1872- 1873).

2. The 1880-1890s, when the mass tin mining started.

3. The 1920s until 1930 Alien Ordinance

Migrants from the above four waves consisted of 5 to 8 major dialect groups from Fujian and Guangdong Provinces in China and have been referred to as the Sin $K e h$ or newcomers to differentiate them from the earlier wave prior to the early $19^{\text {th }}$ century. In the years that followed, some of these later dialect groups that came in waves gained economic dominance over others in the Klang Valley and contributed to the unification of the different dialect groups. ${ }^{3}$ A case in point was when the Chinese faced threats from the Malay and British powers, a Tin Mining Affairs Association was 
formed by the more affluent Selangor Chinese tin miners from the different dialect groups took the path of overlooking their differences and consciously decided to unite together so that they could act as one to safeguard their own community and businesses. $^{4}$

This paper suggests the diaspora of Chinese migrants to foreign lands is due to situational circumstances in the home country and for latter migrants, the hope of striking it rich. To conceptualize Malaysian Chinese ethnicity, dialectal associations' organizing processes is a resource which investigates the ethnicity's construction process from the pre-colonial to the independent period of their adoptive homeland. Former researches included and concentrated on the Chinese community leaders' process of loyalty transformation from ancestral hometown to adoptive homeland. This study will look into the dynamics of the dialect groups and the shift from an immigrant society to that of a local ethnic society.

However, within the large volume of literature concerning ethnic-Chinese community organizations, the role of ethnicity remains under-researched. The research on Chinese dialectal associations continue to be largely dominated by topics such as internal power structures ${ }^{5}$ and transitions over decades. While analyzing the development of Chinese dialectal associations, most research underscores the influence of homeland politics ${ }^{6}$, structural incentives / limitations in host countries, and changing community compositions. ${ }^{7}$ Furthermore, due to the overwhelming influence of transnationalism, the past few decades have seen a rapid surge in research contribution of the roles of dialect groups in building and maintaining the transregional networks within the Malay Peninsula from 1900 to 1941.

From the last two decades of $19^{\text {th }}$ century to the first half of the $20^{\text {th }}$ century, the Klang Valley region's political system shifted from the Malay Sultanate monarchy to the British colonial rule and at the sixth decade of the $20^{\text {th }}$ century, Selangor had shifted from one part of the Federated Malay States to become the main body of a new independent country. In the meantime, the Chinese community in the Klang Valley had moved from the self-autonomous system-Kapitan Cina to be participants in the British political and legislative bodies and finally to represent a new ethnicity of a new country. Yen Ching Hwang explained that the Kapitan Cina's power in Selangor gradually reduced with the British intervention in 1879 in Selangor when the first British Administrator started governing, and the Kapitan Cina powers were curtailed to just imposing of fines, detaining suspects and being judge for undesirable elements during the 1880 s. $^{8}$

In the period from the second half of the $19^{\text {th }}$ Century to the first half of the $20^{\text {th }}$ Century, the Chinese leadership in the Klang Valley had shifted from being Hakka dominated to Cantonese dominated and finally to Cantonese-Hokkien joint leadership. During this era of leadership transformation, there were three iconic cases namely the rivalry for the Kapitan Cina position; the shift of property rights in Kuala Lumpur of the Sin Sze Si Ya Temple and the change of presidentship in the Chinese Chamber of Commerce.

With several decades of internal leadership shift within the dialect groups among the Klang Valley Chinese community, events in the history of the Chinese community within Malaya were prime movers towards integration of the different dialect groups to become one ethnic community. With the aftermath of the revolutions and civil wars in China from the early $20^{\text {th }}$ century up to 1927 , and other external political factors like adverse British local policies on tin and rubber exports, the Great Depression, which was worldwide, and the competitions faced from Japanese manufacturers, the Chinese community in Selangor underwent a transversion of ethnic reconstruction from dialectal group loyalty to one of unity in ethnicity. In this transversion process which arose mainly from issues of safeguarding and protecting 
their livelihood and its sources, there grew a sense of nationalism and patriotism towards their adoptive country. The methods employed in the transversion process were instrumental, contextual and strategic to overcome their issues at hand and which inevitably united them in ethnicity.

\section{The Early Division of the Chinese Community in The Klang Valley}

According to Government records ${ }^{9}$, unequal treatment directed towards Chinese immigrants had their basis in the earlier discriminatory racial ideologies that were practised by the Malay royalty or the colonial authorities. ${ }^{10}$ In the late $19^{\text {th }}$ century, ethnicism together with dialectism played a major role in the Chinese identity of the lives of the Chinese diaspora. ${ }^{11}$ The Chinese Sin Keh (newcomers) who started dialect group organizations were strongly different from the Peranakan who had undergone a process of enculturalization which helped them work within the system. The Peranakanhad overcome their dialectal differences through their many years of coexistence and long history as the earlier Chinese migrants into the Malay Peninsula. Tan named the chasm between the dialects as dialect-ideological isolation that was experienced by the Sin Kehs, whose main obstacle was identifying themselves as localborn in their adoptive-indigenous country. ${ }^{12}$ In the different states of the Malay Peninsula, for instance, in Pahang and Johor, where the Kapitan Cina system existed, they emulated the Peranakan Kapitan Cina system in the Straits Settlements and formed their own identity as a localized Chinese body irrespective of which dialect group the members were from. An exception was the Hakka Sin Kehs in Selangor who clung to individual leadership that was not willing to cross dialectal boundaries. Internal rivalries which arose between the dialect groups were results of keen competition for leadership within the overall Chinese community. This was a typical situation between the Cantonese and the Hokkien groups. Estrangement between these Sin Kehs groups in the Klang Valley produced a negative impact on the relationship of the groups. However, due to external events in China especially the 1911 revolution the supporters of which appealed to overseas Chinese for financial contribution to overthrow the old regime, donations were requested from all Chinese irrespective of dialects. This was an indirect factor for the dialect groups to come together to contribute as one Chinese entity to their ancestral land. Therefore, some forms of unity between the dialect groups came to be established.

There were many other factors that contributed to the shift of emphasis of the different dialect groups from parochialism to their ethnic Chinese identity. In order of intensity, the factors seemed to be class consciousness, ethnic histrionic structure and cultural indigenization. Accompanied by the shift of historical background in the Selangor's ruling power from Malay to British intervention, the Chinese community began to move their original homeland identity to a localized identity with the societal marks which included worship, self -governing patterns, the practice of re-sinicism as a result of differing circumstances. ${ }^{13}$ For instance, the Chinese dialect-groups adopted the Datuk Gong worship as their cross dialectal worship to envelope the dialectal deities of Kuanti or Thean Hou which contributed to a common belief as the result of adaptation and indigenization to the Malay culture. In the domain of ethnic histrionic structure, Chinese associations grew to become industrial organizations irrespective of dialect groups for membership, like the Selangor Miners' Association in 1902 and provincial associations like the Selangor Kwang Tung Association in 1939.

In the realm of Chinese education, Chinese vernacular schools like Tsun Jin were established to replace the Hakkas and Cantonese dialectal private academies. This was a definite move towards a common ethnicity across dialectal boundaries, 
strategically implemented to have changes at the roots for its new generation of Chinese populace.

At the same time, the descendants of the Chinese populace were also opened to Anglo-medium education brought in by the British administration and missionaries. This growing number of western educated Chinese with a common outlook and language for both business and economic communication played a great part in crossing dialectal differences between the Chinese. ${ }^{14}$

According to Mak Lau Fong, class consciousness according to occupational structures as the community became settled and grew, could well be a vital factor in diluting the intensity of dialect group identity. People sharing the same occupational ideology tended to work together in times of conflict within the same occupational class irrespective of which dialect group they belonged to. This seems to be the general and conventional explanation for the close symbiotic relationship between the Hokkiens and the Hakkas in the Klang Valley who belonged to a common working class (plantation and coastal services) in the first to the third decades of the $20^{\text {th }}$ century in Peninsula Malaya.

In the areas of ethnic historical structures, according to dialect groups' occupational- Association structure,the Hokkiens were the first to organize a strong consanguineous association among the different work groups within the Hokkien community, compared to the other Chinese dialect groups in the whole Malay Peninsula which included the Klang Valley in his study of the early $20^{\text {th }}$ century Malaya. ${ }^{15}$ These consanguineous associations seemed to be a link which strengthened the Hokkiens in their pursuit of leadership within the Klang Valley's internal Chinese communities.

As a result of occupational boundaries that existed between the different dialect groups, each group became compartmentalized and had its own work norms and leadership. While dialect differences complemented each other's vocabulary in job terminologies, leadership within the overall Chinese community was to be given to any capable potential leader irrespective of which group he came from. Success in the business world was the main criterion.

Clans were established by the early migrants to give support and to help newcomers orientate themselves to new survival conditions in the new land. They were established according to their Chinese surnames like Ang, Tan, $\mathrm{Ng}$, etc, which indicated their dialects. Benefits of networking were not usually limited to the different clans only but they stretched within the same dialectal community.

However, in 1926 there was an attempt to cross dialectal boundaries when the Cantonese Chan She Shu Yuen Clan Ancestral Hall in Kuala Lumpur adopted Tan clan members from the Hokkien dialect group to participate in the administration of the committee. ${ }^{16}$ This momentous move was probably due to political and natural disaster events that took place in China. Hence, there was thus a need to come together to join forces in a concerted effort to give aid to their ancestral homeland.

Another case of cross-dialectal cooperation was between the Hokkiens and the Hakkas in the 1900s. As the Hokkiens and the Hakkas were the minority dialect groups at that time in the Klang Valley, in order to compete with the socially and economically well-established Cantonese, they had to unite and cooperate, as well as shared all possible resources, including networks for business and leadership within the overall Chinese community. In 1906, when the Chairmanship of the Chinese Chamber of Commerce was vacant, the Hakkas did not have a qualified candidate and had to turn to the Hokkiens to appoint the Hokkien towkay Ang Kim Seng instead of supporting the incumbent Cantonese Chairman Loke Yew. ${ }^{17}$

It is to be noted that even though most of the Hakkas and the Cantonese originated from the same Kwangtung province in mainland China, the Hakkas did not possess a 
parochial consciousness. Thus, in Malaya, the Hakkas found it acceptable to cross provinces and dialect to work together with the Hokkiens to regain their influence in the economy. It was a win-win situation for both parties.

One possible main reason behind the disunity within the Chinese community as a whole was probably due to the different levels of occupational classes they came from. The Cantonese dominated the merchant class, the Hakkas were mainly in the mining industry, plantation and farming sectors, and the Hokkiens and Teochews were mainly from the hawker class. The occupations thus reflected the different dialects and vice versa. Belonging to a common occupational structure seemed to be the impetus for the Hokkiens to cross dialectal boundaries with the Teow Chew which extended ultimately to the Hakkas. Another factor which added to this move towards Chinese ethnicity in Malaya in the early $20^{\text {th }}$ century was the neighbourhood proximity of the dialect groups of the Hokkiens, Hakkas and Teochews. According to Kuala Lumpur dialect group residential distribution map in Kuala Lumpur Chinese Historical Episode, in 1917, the Cantonese were mainly settled in Sultan Street, a distance away from the other groups who lived side-by-side in the neighbourhood. ${ }^{18}$

\section{Rivalry for the Last Kapitan Cina Position Between the Hakka and Cantonese Groups}

In the history of the Chinese Protectorate in Selangor in the decades before and after the Federation (1896), the appointment of the Secretary for Chinese Affairs symbolised the establishment of direct rule over the Chinese population by the British administrators. This transformation did not come as a surprise to the Chinese dialect groups. Rather, it was considered to be an inevitable process of change after some economic and administrative functions of the Kapitan Cina had been transferred to the Protectorate which was set up in the 1880s. Initially, this organization was vested with limited authority and responsibilities to deal with specific Chinese problems which had been formerly undertaken by the Chinese Protectorate office in the state, which provided the link between the British government and the Chinese. The powers of the Secretary were considerably widened when the Secretary for Chinese Affairs Enactment was passed in $1899 .{ }^{19}$ The Enactment ${ }^{20}$ gave control to the Secretary not only in administrative affairs but also fund-disbursement for charity bodies of the Chinese community. The Secretary's responsibility also covered social affairs - he could act as arbiter in domestic disputes and sit on Chinese committees. The Secretary, however, had to take Chinese customs into account when he exercised English law.

In 1889, the $4^{\text {th }}$ Kapitan Cina of Selangor, Yap Ah Shak passed away. The Hakkas elected their head Yap Kwan Seng to succeed Yap Ah Shak. However, this appointment was challenged by the Cantonese when they elected their own headman Chiew Yoke who happened to be a comrade-in-arms with the third Hakka Kapitan Cina Yap Ah Loy (1868-1885) during the Second Selangor Civil War (1872-1873) ${ }^{21}$ : besides he was also an in-law of Yap Ah Loy. ${ }^{22}$ This was the first and the only time that the position of Kapitan Cina had gone through a cross-dialectal challenge among the Chinese community of the Klang Valley. Upon the mediation of the British Resident W.E. Maxwell, Yap Kwan Seng became the last Kapitan Cina of Selangor. As a compromise, two positions - one in the Selangor State Council and another in the Kuala Lumpur Sanitary Board were allocated to Cantonese candidates. ${ }^{23}$

In the early periods of Chinese settlements, the Hakkas were the most dominant group in both population and the economic power in the inland towns of Selangor. However, when the Cantonese followed their footsteps and moved into these towns, Cantonese economic power became more dominant as they overtook that of the 
Hakkas especially in the $1880 \mathrm{~s}^{24}$ For instance, the Cantonese towkays Chiew Yeok, Loke Yew and Chan Sow Lin started their businesses and took up positions in the political arena to represent their Cantonese newcomers. Thus, the Cantonese became a voice to be considered in public affairs. The Hakka group, however, still maintained their power in both the political and economic arenas. The Hakka leaders Yap Kwan Seng and Yap Loong Hin owned many tin mines, pawnbroking shops and brothels, and the Hakka Fui Chiu Association was the largest dialectal association in the State of Selangor at that time. However, Maxwell in the mediation also recognized that Yap Kwan Seng would be accepted by both the Hakkas and Cantonese on the basis that Yap Kwan Seng was from Chih Xi, a Hakka county in Guangzhou Prefecture, the same prefecture that the Cantonese originated from. Yap Kwan Seng was also fluent in both his native Hakka and Cantonese. ${ }^{25}$ His close relationship to Cantonese business elite Loke Yew and Chan Sow Lin to protect their business interests also made it easier for Yap Kwan Seng to be accepted as the Kapitan Cina in Selangor. In addition, his membership in the Selangor Kong Siew Association, the largest Cantonese Association in the Klang Valley, and the Selangor Hakka Association, the second largest Hakka Association in the Klang Valley helped Maxwell justify his choice in Yap Kwan Seng.

The Colonial government played a deciding role in Chinese affairs when in 1900, it established the Selangor Chinese Protectorate and with its replacement of the Kapitan Cina System in 1902. As a result of this move, the conflicts between the different dialect groups and their accompanying secret societies became less recognized and visible.

Yen Ching Hwang's study, however, covered Chinese dialectal structures only up to 1911. In his study, he had stated that 'the greater the power within the Chinese community, the lesser the extent in ethnic-acculturation' ${ }^{26}$ However, with the movement of growing ethnicity due to circumstances described above which all dialect groups experienced, Yen's theory could not be applied. In the 1920s and 1930s, the dialect groups had started to come together and there was ethnic acculturation with dialectal boundaries blurring as leadership was chosen not based on dialects but rather on the track record of the candidate. The coming together of the different dialects is seen in other social aspects of the community as in the recognition of the oneness of worship and business affiliations.

\section{The Shift of Management Rights of Sin Sze Si Ya Temple}

Sin Sze Si Ya Temple, the oldest Chinese temple in Kuala Lumpur was founded by Hakka Kapitan Cina Yap Ah Loy as a memorial to two late Hakka leaders-Kapitan Sheng Ming Li who had been killed in the Sungai Ujong war and Chung Lai, a Hakka Chief commander who fought with Kapitan Yap Ah Loy and was executed by the enemy in the Kuala Kubu battle of the Selangor Civil War. ${ }^{27}$ This temple was built solely for Hakka worshipers. However, when Kapitan Cina Yap Kwan Seng passed away, the Hakka influence declined. In the first decade of the $20^{\text {th }}$ Century, the Sin Sze Si Ya temple's property entrusted rights were transferred from Kapitan Cina to a committee organized by the Chinese community. In 1907, the owners of the Sin Sze Si Ya Temple and the owners of the neighborhood shops had a dispute about the use of the surrounding lands. This dispute was brought to court. As a result from the loss of a powerful Hakka leader Yap Kwan Seng, assistance was sought from Chan Sow Lin, a Cantonese leader and also a member in the Selangor State's Legislative Assembly at that time to settle the dispute. The Hakkas, in gratitude, gave up the Chairmanship of the Sin Sze Ya Temple's Property Trust Committee to Chan Sow Lin. In the later months of 1907, there were 11 new members of the Chinese elite from different Chinese dialect groups elected into this committee: 4 of them were Cantonese, 3 of 
them were Hakkas, 2 of them were Hokkiens, 1 of them was Teochews and another 1 of them was Kwang Sai. Chan Sow Lin made several amendments to the Committee's constitution. For instance, one amendment was that committee members were allowed to keep their seats for lifetime, and they could recommend their successors. Based on this amendment, the Cantonese group controlled the management of this previously Hakka temple for more than three decades until their status was challenged by the Hokkien elite Ang Keh Tho and Tan Seng Kee in the 1940s.

Sin Sze Si Ya Temple was the original place of worship of the deities that protected the Hakka gangs and their members in the Klang Valley was now open for worship to all dialect groups. Consequently, integration and coordination between the different dialect groups was made easier by committee members from the different dialect groups. The Temple became a focal point for the spread of a common ethnicity for all the different dialects living in the Klang Valley and beyond.

\section{The Tauchang Riots in Kuala Lumpur}

After the Cantonese replaced the Hakka's leadership within the Chinese community through several rivalries in the late $19^{\text {th }}$ century and the first decade of the $20^{\text {th }}$ Century, the dialect contraction between the Cantonese and the Hokkien community became the mainstream of conflict within the Chinese community in the Klang Valley during the second decade of the $20^{\text {th }}$ century. Compared to the previous Cantonese Hakka conflicts, the conflicts between the Cantonese and the Hokkien group were more intense, and even developed into bloody riots in 1912. On $18^{\text {th }}$, February 1912 , which was just six days after the overthrown of Chinese Manchu government and barely 7 weeks after the founding of the Republic of China, armed fighting broke out between the Hokkien and Cantonese groups in the downtown of Kuala Lumpur. This dialect groups conflict originated from a case happened a day earlier when a group of Cantonese forced a Hokkien rickshaw puller to cut off his queue as a show of victory of the 1911 Revolution and the end of the emperor system in China. This conflict led to riots that spread to the surrounding towns such as Ampang, Salak South, Sungai Besi, Kajang, Rawang, and others, resulting in heavy casualties and injuries. ${ }^{28}$ The British colonial authority and the local society were shocked by these Chinese dialect riots. ${ }^{29}$ These riots were related to the in-combating among factions for control of their respective territories, and, simultaneously, were regarded as the aftermath enmity between the Revolution party and Royalist party. The Chinese towkays from different dialect groups were called and they held an emergency meeting at the Chinese Chamber of Commerce on $22^{\text {nd }}$ of February 1912, to discuss solutions to the riots. ${ }^{30}$ After this emergency meeting, Loke Chow Kit, the president of the Chamber suggested that the riots between dialects need to be suspended immediately, otherwise the British would start to intervene. ${ }^{31}$ A week later, the Protector and the Resident issued the " Proclamation regarding the Chinese New Year disturbances in connection with queuecutting" on $28^{\text {th }}$ and $29^{\text {th }}$ of February, 1912. ${ }^{32}$ Besides the interventions by the British, the Kuala Lumpur Chinese Confucian Hall, which was controlled by the Chinese Royalist party, also issued "A Vernacular Speech for Settlement of Disturbance' in respect of the queue-cutting riots. Lee Shao Qing, a Hokkien, who served as the secretary of the Confucian Hall, had advised the Chinese from different dialect groups to stop the armed fighting. He pointed out that the Chinese in all over the world had become the new citizens in a new republic and therefore, the local dialect groups must banish all differences among them to form themselves as an ethnic community; otherwise, these dialect riots would become laughing stocks of the other nations especially the British. ${ }^{33}$ 


\section{Presidentship Change in the Selangor Chinese Chamber of Commerce}

The Chinese leadership power shifted from internal administrative-political arena to the business domain since the abolishment of the Kapitan Cina System. In this term, a business organization (in ethnic level) within the Chinese community was founded by several business headmen from different dialect groups. However, the organization had been led by the Cantonese towkays in its early days (1904 -1930). San Ah Wing, a Cantonese business man, advocated an establishment of a new business chamber to deal with the business affairs and issues on $18^{\text {th }}$, February, $1904 .{ }^{34} 4$ days later, several Chinese business headmen gathered in the office of Tong Hin Loong Enterprise (owned by Cantonese leader Loke Yew) to discuss the issues of founding a business Chamber. ${ }^{35}$ In this meeting, Loke Yew and Chan Sow Lin were selected to be the president and vice president of this new chamber. This chamber had been registered with the British colonial authority on $27^{\text {th }}$ March $1904 .{ }^{36}$ This organization was called Shangwuju (商务局) and later renamed as the Selangor Chinese Chamber of Commerce. The establishment of the Chamber transcended the traditional Chinese practices of forming social groups along the lines of dialects, provincial origins and occupations. This Chamber were founded and led by the most reputable and powerful Chinese elites at that time. It functioned as a public and open platform for its members to engage, construct networks between members and consolidate ideas, and most significantly, it also served as the highest representative body, socially, economically and politically of the Chinese community in the Klang Valley before the World War II. Table 1 is the list of the president and vice president with their dialect attributes.

\section{Table 1 Presidentship of the Chinese Chamber of Commerce (1904-1941) ${ }^{37}$}

\begin{tabular}{|c|c|c|c|c|}
\hline Tenure & President & $\begin{array}{l}\text { Dialect } \\
\text { Attribute }\end{array}$ & Vice- President & $\begin{array}{l}\text { Dialect } \\
\text { Attribute }\end{array}$ \\
\hline 1904-1907 & Loke Yew & Cantonese & Chan Sow Lin & Cantonese \\
\hline 1907-1909 & Chan Sow Lin & Cantonese & Loke Chow Kit & Cantonese \\
\hline 1909-1910 & Choo Cheng Kay & Hakka & San Ah Wing & Cantonese \\
\hline 1910-1911 & Loke Chow Kit & Cantonese & Loke Chow Thye & Cantonese \\
\hline 1911-1914 & Loke Chow Thye & Cantonese & San Ah Wing & Cantonese \\
\hline 1914-1917 & Yap Loong Hin & Hakka & San Ah Wing & Cantonese \\
\hline 1917-1930 & Loke Chow Thye & Cantonese & Wong Po Chee & Cantonese \\
\hline 1930-1932 & Low Leong Gan & Hokkien & Choo Kia Peng & Teo Chew \\
\hline 1931-1935 & Lai Tet Loke & Hakka & $\begin{array}{l}\text { Cheong } \quad \text { Yoke } \\
\text { Choy }\end{array}$ & Cantonese \\
\hline 1935-1936 & Yong Shook Lin & Hakka & $\mathrm{Ng}$ Teong Kiat & Hokkien \\
\hline 1936-1940 & $\mathrm{Ng}$ Teong Kiat & Hokkien & Ang Chin Chong & Hokkien \\
\hline 1940-1941 & Lee Hau Shik & Cantonese & Ang Chin Chong & Hokkien \\
\hline
\end{tabular}

Source: Shanghuihuixun 2000 (Magazine of the Selangor Chinese Chamber of Commerce), Kuala Lumpur: KL. Selangor Chinese Chamber of Commerce, 2000, pp.68-69. and the presidents' dialect attributes were categorized by author. 
We can see from the table, that in the Selangor Chinese Chamber of Commerce, the Cantonese mastered the presidentship for three terms (1904-1909), (1911-1914), (1917-1930), and monopolized the vice president seat of the Chamber for 26 years, only two Hakka business headmen held the chair for a short-term. This situation indicated that the Cantonese business strength had impacted on the social organization within the Chinese community.

It was the turning point in 1930 when the Hokkien towkay Low Leong Gan and the Teochew towkay Choo Kia Peng had taken over the president and the vice president posts within the chamber from the Cantonese towkay's hands. Finally, the monopoly of leadership power within this ethnic business organization was broken. During the 1930s, the presidentship and vice presidentship of this chamber were successively mastered by the towkays from four different dialect groups which indicated the leadership-discretization among different dialect groups within the overall Chinese ethnicity.

\section{Change of Presidentship in Selangor Chinese Assembly Hall}

Besides the Selangor Chinese Chamber of Commerce, the other representative social body within the Chinese community at that time was the Selangor Chinese Assembly Hall. This Assembly Hall was established by the Cantonese business headman Cheong Yoke Choy in 1934, and it has been the second largest and influential Chinese organization in the Klang Valley region to date. As the Cantonese contributed to the Chinese community philanthropic events like donation drives for Chinese vernacular schools and the sponsorship to Chinese hospitals like the Tong Shin Hospital in the first three decades of the $20^{\text {th }}$ century, the Cantonese were inevitably open to ethnic integration within the different dialect groups. As the mass migration wave into the Malay Peninsula was suspended in 1930 due to the Aliens Ordinance 1930 implemented by the colonial authority, migration from mainland China was restricted to female newcomers. Thus, migration patterns in the Malay Peninsula shifted from bulk overseas migration to domestic migration as the Chinese community moved from the other states into the Klang Valley which in a way contributed to the growth of Hokkien proliferation into the Klang Valley as indicated in Table 2. ${ }^{38}$

Table 2 The Hokkien Population in the Klang Valley from 1929 to 1933

\begin{tabular}{|l|l|l|l|l|l|}
\hline Year & $\begin{array}{l}\text { Existing } \\
\text { Population }\end{array}$ & $\begin{array}{l}\text { Domestic } \\
\text { arrivals }\end{array}$ & $\begin{array}{l}\text { International } \\
\text { arrivals }\end{array}$ & Total & $\begin{array}{l}\text { Proportion } \\
\text { of Growth }\end{array}$ \\
\hline 1929 & 22371 & 1371 & 983 & 24725 & - \\
\hline 1930 & 24725 & 1466 & 492 & 26683 & $7.68 \%$ \\
\hline 1931 & 26683 & 2214 & 407 & 29304 & $9.82 \%$ \\
\hline 1932 & 29304 & 3197 & 396 & 32897 & $12.26 \%$ \\
\hline 1933 & 32897 & 4041 & 387 & 37325 & $13.46 \%$ \\
\hline
\end{tabular}

Source: Selangor Annual Report 1929-1933; Klang Hokkien Association 50 years Anniversary Magazine

Based on the above information, the total number of Hokkiens in the Klang Valley expanded from 24,725 in 1929 to 37,325 in 1933, that was an increase of 66. $8 \%$ in 1933. As a result of the implementation of the Aliens Ordinance 1930, the influx of Chinese migrants dropped drastically, but the Hokkiens' population in the Klang Valley increased due to migration from the other areas of the Malay Peninsula. 
Domestic migration increased from over a thousand in 1929 up to over 4 thousand in 1933. The highest number of migrants came in 1933 which were mostly from internal arrivals. The structure of dialect groups within the Chinese community in the Klang Valley changed as a result of internal migration of the Hokkiens and the Aliens Ordinance.

The move of the Hokkiens to the Klang Valley was also because of job attractions and other economic opportunities that came along in the development of the economic and political center in the Klang Valley. The changes on the population structure of the Cantonese and Hokkien dialect groups are indicated in Table 3.

\section{Table 3: Cantonese and Hokkien population proportion in the Klang Valley before and after the 1930 Aliens Ordinance}

$\begin{array}{llllll}\text { Year } & \begin{array}{l}\text { Chinese } \\ \text { Population }\end{array} & \begin{array}{l}\text { Hokkien } \\ \text { Population }\end{array} & \text { Proportion } & \begin{array}{l}\text { Cantonese } \\ \text { Population }\end{array} & \text { Proportion } \\ \mathbf{1 9 2 9} & 94426 & 24725 & 26.18 \% & 36629 & 35.62 \% \\ \mathbf{1 9 3 4} & 115375 & 37325 & 32.35 \% & 38073 & 33.54 \% \\ \text { Increase } & 20949 & 12600 & 6.17 \% & 1444 & -2.08 \%\end{array}$

Source: Del Tufo, M.V. 1949. Malaya comprising the Federation of Malaya and the Colony of Singapore: A Report on the 1947 Census of Population, London: Crown Agents for the Colonies.

From Table 3, the overall Chinese population in the Klang Valley increased from 94,426 in 1929 to 115,375 in 1934. However, the increase was due to the influx of Hokkiens into the valley, while the proportion of the Cantonese dropped even though there was a minimal increase in the number of Cantonese in the valley.

The ban on mass migration from China affected the Cantonese proportion of the Chinese population as they depended heavily on labor from China. The Hokkiens on the other hand, had settled in the Malay Peninsula since the $16^{\text {th }}$ Century and thus had a bigger localized population and were not as badly affected by the Aliens Ordinance 1930. They could move their business contacts and expertise from the different parts of the Malay Peninsula to the Klang Valley without waiting for labor from mainland China. Another contributory factor that tipped the balance of the dialect groups in the Klang Valley was the Hokkien characteristic of being less inhibitive and more open in their business networks.

They were able to assimilate into the existing community faster vis-a- vis the Cantonese businessmen. This move was also seen to be to the attribute to the shift of the Hokkien economic activities from the west coast to the Klang Valley. However, business operations between the Hokkiens and the Cantonese were slightly different in methodologies. For instance, the Hokkien businessman's business acumen was of an all-round approach. While the Cantonese confined their businesses to their own dialect group and sought political support from the colonial government. Moreover, the Hokkiens mobilized their masses to settle in the Klang Valley and at the same time they set up their businesses and social bodies to enhance their business opportunities. The difference in strategy by the Hokkiens may have pitted well against the economic strength of the Cantonese businessman.

The Hokkien leadership, compared to that of the Cantonese, had some special features. Firstly, the Hokkiens started to build political organizations such as the group organized by the Ang Keh Tho, which later became a branch of the Malayan Chinese Association, ${ }^{39}$ whereas the Cantonese were still concerned about gaining a seat in the State Legislative Council under the British. But the post second world war 
changed the perspectives of politics in Malaya, and the Chinese in Malaya were required to play their role as local citizens of Malaya instead of either British subjects or citizens of KMT China in the face of fighting for the independence of the country from colonial powers.

The Hokkiens including the Peranakan Chinese group had already shifted their loyalty to the Malay Peninsula ${ }^{40}$,their adoptive homeland for several decades. According to Yen (1983) and Yong (1991), the Hokkien's political awareness were comparatively higher than the Cantonese group. ${ }^{41}$ A portion of the Cantonese remained apolitical while a portion of Hakkas still owed their loyalty to mainland China.

Moreover, the Hokkien leaders' cross dialectal participation and integration into the local life which was frequently referred to as 'exemplary' ${ }^{42}$ which the other dialect groups could not yet emulate. For instance, in 1937, the Hokkien ability to set up a committee for financial support in the Anti- Japanese movement was a move at integrating the different dialect groups for a common cause. In comparison, the Cantonese and Hakka leaders had no foresight nor saw the need for a united effort for a common cause.

Because Hokkien leadership brought about the different dialect groups together, there was a need for a common language to communicate with the different dialects. In 1920s, the Hokkiens advocated the use of Mandarin Chinese in all official communication, whereas the Cantonese were still trying to promote the Cantonese dialect as the common business dialect in the Klang Valley. ${ }^{43}$

These differences illustrated the gap between the Hokkiens and the Cantonese in their concept of ethnicity. As far as a common language for communication is concerned, the Cantonese preferred to use their dialect, and it was still not accepted as the official language of communication between the dialect groups within the Chinese community. According to Tso (1973), ${ }^{44}$ Mandarin was a dialect in ancient China but since the 1911 revolution, Mandarin became the national language adopted to overcome the regional isolationism that existed in China. In Malaya, the Hokkiens gyrated towards a common language for communication and advocated the use of Mandarin not only to communicate but also to unite the different dialect groups which inevitably brought about a common ethnic identity for the Chinese.

One other factor in the shift of leadership pattern within the Chinese community was the ability of the Hokkiens to have a comparatively stronger coordinating skill on the different dialect groups. Unlike the Hokkiens, the Cantonese found it difficult to give full support to common charitable projects, for example, in the building of the extension to the Tung Shin Hospital. ${ }^{45}$ In the allocation of cemetery land, the Hokkiens seemed to have done better in obtaining a larger piece of land than the other dialect groups. They also possessed good skills for efficient management of organizations, thus increasing their capacity role as leaders within the Chinese community. By nature, the Hokkien leaders were more willing to sacrifice their dialectal identity to pursue higher goals of Chinese ethnic identity and to encourage and construct nation building of the Chinese in the new homeland. Well thought out organizational strategies by the Hokkiens in the implementation of common community plans were also contributory to the rise of Chinese ethnic awareness and the loyalty concept towards the Malay Peninsula. 


\section{Rise of Patriotism and Nationalism of Chinese Dialect Groups in Malaya}

By the early $20^{\text {th }}$ Century, some groups of the Chinese elite gradually made decisions to move their loyalty to Malaya which had given them a livelihood. However, there were groups of other Chinese who still had strong ties with mainland China and maintained dual citizenships of being a Chinese citizen and a British subject. This opportunistic behavior was exploited by many Chinese businessmen in the Klang Valley, who had already obtained their citizenship as a British subject but still wanted the appointment of the Consul of the Chinese by the mainland China government in the Malay Peninsula for political recognition. Hakka leaders like Cheong Fatt Sze and Leong Fei, Cantonese leaders like Eu Tong Sen, Chan Sow Lin and Loke Yew were examples of takers of dual citizenship. ${ }^{46}$

One of the factors that the Chinese in Malaya considered dual citizenship was the Sino-Japanese conflict (1914-1915) which ignited patriotism to the motherland. ${ }^{47}$ However, they were faced with the dilemma of allegiance to China and loyalty to the land that they had thrived on. This sense of split consideration was the impetus which brought them to the cross-roads of where to owe their allegiance to. In the search for a solution to this issue, the local Chinese had to decide, and in that decision-making process they had to inevitably look at themselves as a united ethnic group rather than individual dialect groups. The spirit of patriotism and nationalism was now being stoked in the Chinese as an ethnic group in the emerging independence of the country of their adoption. A major consideration for a solution was the need to safeguard the businesses that they had built from scratch. In this effort, dialectal differences which were part of their weaknesses to unity had to be subsumed and overcome.

In addition, two decades later, with the implementation of 1930 Alien Ordinance which resulted in a drop in Chinese mass migration into the Malay Peninsula in 1930s, the outlook of the prototype of the Chinese who had settled in the Klang Valley changed from being migrants to one who had begun to grow roots locally. Since the 1930s, also, new generations of local born Chinese had lived in and organized their own communities into different business associations and affiliations within the Klang Valley and throughout the Malay States. Such localized activities stemming out of local conditions weakened the connections of ancestral hometown and mainland China, and thus provincial/ dialectal ties. Instances of leadership within this new generation in the Selangor Chinese society are seen in the leadership of Alan Loke (Cantonese), Yap Loong Hin (Hakka), Khoo Teik Ee (Hokkien), Yong Shook Lin (Hakka) and San Ah Wing (Cantonese). ${ }^{48}$

One common and substantive factor that cannot be overlooked was the colonial English school education which most of the localized younger generation had undergone, either locally or overseas. ${ }^{49} \mathrm{~A}$ common educational background and language of communication in English helped overcome cross-dialectal inhibitions which resulted in business co-operations and cross- dialectal family structures. The educated elite leadership in a way seems to be a strong factor in galvanising the rest of the dialectal groups to not see their different dialects as a barrier to an ethnic unity which has become the basis of the Malaysian Chinese today.

The ethic unity process was further encouraged during the period of the SinoJapanese war (1937-1945). Appeals for financial support were made to overseas Chinese in the war against the Japanese and in response to that call, the Selangor Chinese Relief Fund Committee(雪兰莪华侨筹赈中国委员会) was established in 1937 and the South Seas Federation of China Relief Funds Association(南侨总会) in 1938. Different dialect groups came together for a common cause even though it was external in nature. It proved that the different groups could be united. 
Table 4: Members of Selangor Chinese Relief Fund Committee with Dialectal Attributions

\begin{tabular}{|l|l|}
\hline Chairman & Lee Hau Shik (Cantonese) \\
\hline Vice-Chairmen & Ang Chin Chong (Hokkien), Lai Tet \\
& Loke (Cantonese) \\
\hline Treasurer & Cheong Yoke Choy (Cantonese) \\
\hline Vice-Treasurers & Chan Chin Mooi (Cantonese), Chin \\
& Yin Ruan (Hakka) \\
\hline Shareholders & San How Chee (Cantonese), Low Kee \\
& Boo (Hokkien), Chong Khoon Lin \\
& (Hakka) \\
\hline Executive Board Members & Cho Yew Fai (Cantonese), Lim Say \\
\hline Secretary & Gim (Hokkien) \\
\hline Media Board & Chin Kok Thun (Hakka) \\
\hline Standing committee & Chin Chew Meow (Hakka), Choo \\
\hline & Chick Sang (Teochew) \\
\hline & Lee Hau Shik, Lai Tet Loke, Cheong \\
\hline & Yoke Choy, Cho Yew Fai, San How \\
& Chee, Chan Poon Chor (Cantonese) \\
\hline & Ang Chin Chong, Ng Tiong Kiat, Yap \\
& Yong Khean(Hokkien) Chong Khoon \\
\hline & Lin, Chin Yin Ruan (Hakka) \\
\hline
\end{tabular}

Source: Sin Chew Jit Poh, 28 ${ }^{\text {th }}$, August, 1937, p11

Hokkiens shared leadership power even though the Chairman was Cantonese. In normal practice, power was in the hands of the Vice Chairmen. In this case, according to a report in Sin Chew Jit Poh in $28^{\text {th }}$ August 1937, the Hokkien-Ang Chin Chong played a more active role than the Cantonese Chairman. ${ }^{50}$. On the positions of Vice Treasurers, the Cantonese representative was slightly more senior than the Hakka and thus had a greater influence. ${ }^{51}$ From the table, it can be seen that leadership power was distributed fairly equally between the Cantonese and the Hokkiens in the Selangor Chinese Fund Committee. In 1938, the committee was more open to other dialects - the Hakkas and the Teo Chius, indicating a significant shift to cross-dialectal unity in the face of a common task or threat.

Another such set up for mainland China funds was the South Seas Federation of China Relief Funds Association (南侨总会) was established on $10^{\text {th }}$ October 1938. It was led by the Hokkiens (Table 4). The Selangor Branch was operated by 2 Hokkien members, 2 Cantonese and a Hakka all of whom were nominated by the Singapore headquarters led by the Hokkien legendary leader Tan Kah Kee, (Stephen Leong 1976) ${ }^{52}$ and it went across dialectal boundaries thus distributing power among the different groups and not concentrating power on any one dialect group. 
Table 5: South Seas Federation of China Relief Funds Association at Singapore Headquarters

\begin{tabular}{|c|c|c|c|c|}
\hline Position & Name & $\begin{array}{l}\text { Chinese } \\
\text { name }\end{array}$ & $\begin{array}{l}\text { Dialectal } \\
\text { Attribution }\end{array}$ & $\begin{array}{l}\text { Residential } \\
\text { Place }\end{array}$ \\
\hline $\begin{array}{l}\text { Secretary, } \\
\text { Headquarters }\end{array}$ & $\begin{array}{ll}\mathrm{Ng} & \text { Tiong } \\
\text { Khat } & \end{array}$ & 黄重吉 & Hokkien & Klang \\
\hline $\begin{array}{l}\text { Deputy Head, } \\
\text { Selangor } \\
\text { Branch } \\
\text { (Executive) }\end{array}$ & $\begin{array}{l}\text { Ang Chin } \\
\text { Chong }\end{array}$ & 洪进聪 & Hokkien & Kuala Lumpur \\
\hline $\begin{array}{l}\text { Deputy Head, } \\
\text { Selangor } \\
\text { Branch } \\
\text { (Finance) }\end{array}$ & $\begin{array}{l}\text { Chan Chin } \\
\text { Mui }\end{array}$ & 陈占梅 & Cantonese & Kuala Lumpur \\
\hline $\begin{array}{l}\text { Head, } \\
\text { Selangor } \\
\text { Branch }\end{array}$ & $\begin{array}{ll}\text { Lee } & \text { Hau } \\
\text { Shik } & \end{array}$ & 李孝式 & Cantonese & Kuala Lumpur \\
\hline $\begin{array}{l}\text { Executive } \\
\text { Member, } \\
\text { Headquarters }\end{array}$ & $\begin{array}{l}\text { Wong Yik } \\
\text { Tong }\end{array}$ & 黄益堂 & Hakka & $\begin{array}{l}\text { Ulu Langat and } \\
\text { Seremban }\end{array}$ \\
\hline
\end{tabular}

Source: Stephen Leong Mun Yoon. "Source, Agencies and Manifestations of Overseas Chinese Nationalism in Malaya, 1937-1941." PhD Thesis, University of California, P76, Tan Miau Ing: Tun Sir Henry Lee Hau Shik. Ahli Perniahaan dan Tokoh Politik [Tun Sir, Henry Lee Hau Shik, A Business member and Political Character]. Kuala Lumpur: Penerbit Universiti Malaya, (University of Malaya Press) 2018. P79, Sin Chew Jit Poh October 19 1938.

It is apparent from Tables 3 and 4 that leadership was being shared between the different dialects and that shared leadership was accepted by all as a means of achieving a goal. This was evident when $90 \%$ of the Chinese associations became members of the South Seas Federation of China Relief Funds Association. ${ }^{53}$

Based on Sin Chew Daily and the Nanyang Siang Pao ${ }^{54}$, the Hokkien group members played a significant role in the running of the headquarters of the organization in Singapore. ${ }^{55}$ The Hakkas even though they had a seat in the headquarters did not enjoy equal power. On the other hand, the Cantonese headed the Selangor Branch. However, the actual power of this branch was vested in two deputy heads, the executive function by a Hokkien and the finance by a Cantonese.

\section{Progress of Cross Dialectal Integration Between Chinese Organizations}

Voon Ping Keong in his massive research on ethnography and census data on different Chinese dialect groups unfolded the interaction patterns of the early Chinese migrants in the Klang Valley. On the one hand, the interaction patterns could be redefined as the concept of locality based on the instrumental principle of occupations and dialectalcultural elements. It was conceptualized as a solidarity reinforcer of unity in that it blurred boundaries between the different dialect groups. On the other hand, Mak Lau 
Fong brought to attention a kind of social bond that existed between the dialect groups in the sharing of limited resources in times of survival when communal resources became scarce, ${ }^{56}$ which eventually brought about a spirit of cooperation among the dialect groups.

A few Hakkas such as Yap Ah Loy and Yap Kwan Seng, had also excelled in the tin mining industry in early Malaya, but the Cantonese on the whole dominated, if not monopolized the more lucrative businesses and occupations of opium farming, pawnbroking and Chinese banking from the late $19^{\text {th }}$ century to the early $20^{\text {th }}$ century in the Klang Valley. ${ }^{57}$ According to British Reports, the Cantonese group was expert in investment and the Hokkiens were adept at trades. Both Cantonese and Hokkien members were comparatively better than the Hakkas in some business fields like pawnbroking and retailing. ${ }^{58}$ These qualities might be the main factors that led to the dominance of the Cantonese and Hokkiens in the Chinese community's leadership in the Klang Valley.

Table 6: Different Types of Chinese Organizations in Selangor in 1941

\begin{tabular}{|l|l|}
\hline $\begin{array}{l}\text { Organization } \\
\text { Types }\end{array}$ & Total Number \\
\hline Religious & 4 \\
\hline Clan & 14 \\
\hline $\begin{array}{l}\text { Regional } \\
\text { Association }\end{array}$ & 23 \\
\hline Social & 19 \\
\hline Sports & 3 \\
\hline Welfare & 24 \\
\hline Industrial & 26 \\
\hline Cultural & 6 \\
\hline Others & 7 \\
\hline $\begin{array}{l}\text { Special } \\
\text { (Non- } \\
\text { categorized) }\end{array}$ & 3 \\
\hline Total & \\
\hline
\end{tabular}

Source: Wan Ming Sing. "The History of the Organizations of the Chinese community in Selangor with Particular Reference to Problems of Leadership, 1857-1962." MA Thesis, University of Malaya, 1967. Compilation from The Selangor Chin Woo Sports Association Gazette, The 1960 Annual of Selangor Mining Association, Tung Shin 80 Years Anniversary Magazines, 1962.

As illustrated in Table 6, Chinese organization types in 1941 were already moving from dialectal orientation to a wider orientation of social and industrial groupings for functional purposes. The Chinese community was evolving steadily into a mutual ethnic consciousness as it became more open to changes in demands by industries and other needs in the economy. 


\section{Conclusion}

This article has gone through the roles and power shifts of the three major Chinese dialect groups in their journey towards Chinese ethnic unity in an adoptive land from their different dialect groups that arrived en masse from a country that they knew only as counties and provinces with their individual dialects. They have gone through the formation of dialectal associations for survival in a new land to associations that were opened to the other dialects. Nonetheless, they made efforts to maintain their own individual dialects as they moved towards unity in the face of meeting social, economic and political challenges to become one ethnic group in the fight for economic and social rights in the land which they helped to build.

The early $20^{\text {th }}$ century was an important period for the Chinese in the transfer of their identity of being subjects of an ancestral county to an adoptive homeland. The internal economic rivalries and struggles for the Chinese society leadership between different dialect groups were eventually replaced by a move towards ethnic integration.

The Hakka, Cantonese and Hokkien groups' individual stories in the Klang Valley illustrated that historical networks among the Chinese dialect groups were contributory to Chinese dialectal integration. The Klang valley region, which was (and still is) the central economic area of the Malay Peninsula, maintained the Chinese society's dialectal power structure and the process of power transformation, which was slightly different from some in the other states of the Malay Peninsula.

The stories about the rivalry of the Kapitan Cina position, the shift of the Chinese temple property rights and the leadership struggle in the Chinese Assembly Hall in the Klang Valley region demonstrated the strong dialectal boundaries that existed and were only overcome in the diversion to Chinese ethnicity. This diversion seems to have originated from class consciousness, ${ }^{59}$ which tended to differentiate groups not only along dialect lines, but also within some physical parochial areas from which they came.

On the one hand, the Chinese dialect diversion came about due to external influences in the economic domain, cultural field and political arena within the Malay Peninsula. On the other hand, factors external to the Malay Peninsula came from mainland China itself and led to the establishments of Selangor Chinese Relief Fund Committee and the South Seas Federation of China Relief Funds Association, which resulted in the cross-dialectal coordination and integration movements led by the Hokkiens. These cases were instrumental in the construction of Chinese ethnicity in their adoptive homeland.

Chinese ethnicity in the first half of the $20^{\text {th }}$ century was best understood as a dynamic, constantly evolving property of both individual dialectal identity and group organizations which were reflective of their ancestral hometown districts. The constructions of a new Chinese ethnic identity and culture were the results of social, economic and political requirements, both internal in Malaya and external in mainland China. ${ }^{60}$

\section{Note}

* Wen Wei (aha160023@gmail.com) is a Ph.D candidates in History Department, Faculty of Arts \& Social Science, University of Malaya.

** Datuk Professor Dr. Danny Wong Tze Ken (dannyw@um.edu.my) is a Dean of the Faculty of Arts and Social Sciences, University of Malaya. 
${ }^{1}$ Francis Lok Kok Wah, Beyond the Tin Mines: Coolies, Squatters, and New Villagers in the Kinta Valley, Malaysia, 1880-1980, Kuala Lumpur: Oxford University Press, 1988, pp.20-103.

${ }^{2}$ Mak Lau Fong, The dynamics of Chinese dialect groups in early Malaya, Singapore: Society of Asian Studies, 1995, pp. 103-105.

${ }^{3}$ Mak Lau Fong, The Sociology of Secret Societies; A Study of Chinese Secret Societies in Singapore and Colonial Malaya, New York: Oxford University Press, 1981, p. 47.

${ }^{4}$ Victor Purcell, The Chinese in Malaya, London: Oxford University Press, 1948, pp. 68-69.

${ }^{5}$ Wang Gung Wu, Do Not Leave Home: Migration and the Chinese. Singapore: Eastern University Press, 2002, pp.78-80.

${ }^{6}$ Koh Keng Wei, "Eu Tong Sen: a case study in business expansion". M.A. Dissertation, National University of Singapore,Singapore, 2000, pp.97-103.

${ }^{7}$ Mak Lau Fong, The Dynamics of Chinese Dialect Groups in Early Malaya, Singapore: Society of Asian Studies, 1995, pp.123-124.

${ }^{8}$ Yen Ching Hwang, Class Structure and Social Mobility in the Chinese community in Singapore and Malaya, 1800-1911, Singapore: Time Academy Press, 1995, pp.153-162. Also See FCO 141 and Tan Gaik Yeong, 'British Economic Policy towards the Malays in the Federated Malays in the Federated Malay States 1921 - 1934.' M.A. Dissertation, History Department, University of Malaya, 1969, pp.73-74.

${ }^{10}$ Emily Sadka, The Protected Malay States. Kuala Lumpur: University of Malaya Press, 1968, pp.142-147.

${ }^{11}$ Yen Ching Hwang, A Social History of The Chinese in Singapore and Malaya 1800-1911, Singapore: Oxford University Press, 1986, pp.117-119.

${ }^{12}$ Tan Chee Beng, Chinese Overseas: Comparative Cultural Issues, Hong Kong: Hong Kong University Press. pp.142-148.

13 William Tai Yuen, Chinese Capitalism in Colonial Malaya: 1900-1941, Bangi: Pernabit Universiti Kebangsaan Malaysia (UKM Press), 2013, pp. 135-150.

${ }^{14}$ Souvenir Magazine of the 100 Years Anniversary of the Selangor Kwong Siew Association, Kuala Lumpur: Kuala Lumpur Selangor Kwong Siew Association, 1987, pp.19-21.

${ }^{15}$ Wang Fu Bing, Ma lai ya hua ren de fang yan qun fen bu yu zhi ye jie gou, 1800-1911( The Chinese Dialect Groups' Distribution and Occupational Structure in Malaya, 1800-1911), Kunming: Yunnan Arts Press,2012, pp.73-74.

${ }^{16} 100$ Anniversary Commemoration Magazine of Selangor Hokkien Association, Kuala Lumpur: KL. Selangor Hokkien Association, 1985, pp.16-20.

${ }^{17}$ William Tai Yuen, Chinese Capitalism in British Malaya: 1900—1941, Bangi; Pernabit Universiti Kebangsaan Malaysia (UKM Press), 2013, p.343.

18 Wen Gu Zhi, Ji Long Po Hua Ren Shi Hua (Kuala Lumpur Chinese Historical Episode). Kuala Lumpur: Mentor Publishing Sdn. Bhd, 1984, p.39.

${ }^{19}$ Victor Purcell. The Chinese in Malaya, London: University of Oxford Press, 1948, pp.66-76.

${ }^{20}$ FCO 141 and Tan Gaik Yeong. 'British Economic Policy towards the Malays in the Federated Malays in the Federated Malay States 1921-1934.' M.A. Dissertation, Kuala Lumpur, University of Malaya, 1969, p.86.

${ }^{21}$ J.M. Gullick, Kuala Lumpur, 1880-1895, Singapore: Malayan Branch of the Royal Asiatic Society, 1955, pp.26-45.

${ }^{22}$ Yik Khuan Pao, 13 May, 1919.

23 Selangor Kwong Siew Association 130 Anniversary Magazine, Kuala Lumpur: Kuala Lumpur Selangor Kwong Siew Association, 2017, pp.41-50.

${ }^{24}$ Seventieth Anniversary Commemoration Magazine of Selangor, Kuala Lumpur: Selangor Kwong Siew Association, 1957, p.36, pp.56-57.

${ }^{25}$ Arkib Negera Malaysia, File No.1957/010382, ‘Towkay Loke Yew’s Ulu Bernam Concession'.

${ }^{26}$ Yen Ching Hwang, Class Structure and Social Mobility in the Chinese community in Singapore and Malaya, 1800-1911, Singapore: Oxford University Press, 1986, p.422, The Fui Chiu Association 140 Anniversary Magazine, Kuala Lumpur: Selangor Fui Chiu Association, 2004, p.142.

27 Selangor Kwangtung Association 80 Anniversary Magazines, 2009, pp.49-50.

${ }^{28}$ Ser Wue Hiong, (eds), Moving Mountains, Kuala Lumpur: Centre of Malaysian Chinese Studies, 2013, pp. 48-49.

${ }^{29}$ Arkib Negara Malaysia, File No. 1957/0215211.

${ }^{30}$ Arkib Negara Malaysia, File No. 1957/0162060.

${ }^{31}$ Arkib Negara Malaysia, File No. 1957/0215211.

${ }^{32}$ Ser Wue Hiong, 2013, (eds), Moving Mountains, pp. 50-51. Kuala Lumpur: Centre for Malaysian 
Chinese Studies.

33 Arkib Negara Malaysia, File No. 1957/0162060.

${ }^{34}$ The Malay Mails, 19 February, 1904.

${ }^{35}$ The Malay Mails, 26 February, 1904.

${ }^{36}$ The Malay Mails, 28 March, 1904.

${ }^{37}$ Shanghuihuixun 2000 (Magazine of the Selangor Chinese Chamber of Commerce), Kuala Lumpur: KL. Selangor Chinese Chamber of Commerce, 2000, pp.68-69. and the presidents and vice presidents' dialect attributes were categorized by author.

38 Annual Report on the Social and Economic Progress of the People of Selangor,1930, Kuala Lumpur: Federated Malay States Government Press. pp.21-32.

${ }^{39}$ Tan Miau Ing, The Formation of the Pre-War Leaders of Malaya: H.S. Lee as a Case Study, Journal of Malaysian Chinese Study, Kuala Lumpur: Centre for Malaysian Chinese Studies,17. (2014). pp.1736.

${ }^{40}$ Yen Ching Hwang, Class Structure and Social Mobility in the Chinese community in Singapore and Malaya, 1800-1911, Singapore: Oxford University Press, 1986, pp.93-98.

${ }^{41}$ Yong Chin Fatt, Chinese Leadership and power in Colonial Singapore and Malaya, Singapore: Oxford University Press, 1991, pp.61-76.

${ }^{42}$ Stephen Leong Mun Yoon, "Source, Agencies and Manifestations of Overseas Chinese

Nationalism in Malaya, 1937-1941.” PhD Thesis, University of California, 1976. pp.147-596.

${ }^{43}$ Yong Chin Fatt, Chinese Leadership and power in Colonial Singapore and Malaya. Singapore: Oxford University Press, 1991, pp.103-107.

44 Tso Wen Yi, "Min Guo Chu Qi De Guo Yu Yun Dong(The promotion of National language movement on the early period of the Republic of China)", M.A. Dissertation, National Culture University, Taiwan, 1973, pp.27-33, 102-109.

${ }^{45}$ Selangor Kwong Siew Association 130 Anniversary Magazine, Kuala Lumpur: Kuala Lumpur and Selangor Kwong Siew Association, 2017, pp.18-24.

46 Stenphenie, Chung Po-Yin.2002. "Surviving Economic Crisis in Southeast Asia and southern China: The History of Eu Yan Sang Business Conglomerate in Penang, Singapore, and Hong Kong", Modern Asian Studies, vol.36, no 3, pp. 579-617.

${ }^{47}$ Lee, Sharon M. "Female Immigrants and Labour in Colonial Malaya: 1860-1947." International Migration Review 23, No.2 (1989): pp.309-331.

48 Stephen Leong Mun Yoon, "Source, Agencies and Manifestations of Overseas Chinese Nationalism in Malaya, 1937-1941." PhD Thesis, University of California, Los Angles, The United States of America, 1976, pp.76-79.

${ }^{49}$ Lee Ting Hui, Chinese School in Peninsula Malaysia: The Struggle for Survival. $\quad$ Singapore: Institute of Southeast Asia Studies, 2011, pp.18-19.

${ }^{50}$ Selangor Hokkien Association, 100 Anniversary Commemoration Magazine of Selangor Hokkien Association, 1985, pp.24-25.

${ }^{51}$ Tan Miau Ing, Tun Sir Henry Lee Hau Shik. Ahli Perniagaan dan Tokoh Politik, Kuala Lumpur: Penerbit Universiti Malaya (University of Malaya Press), 2018, p.72.

52 Stephen Leong Mun Yoon, "Source, Agencies and Manifestations of Overseas Chinese Nationalism in Malaya, 1937-1941.”, Ph.D. Thesis. University of California, Los Angles, The United States of America,1976, pp.112-119.

${ }^{53}$ Ibid, p.438.

${ }^{54}$ Nanyang Siang Pao, 18 October, 1938.

55 Sin Chew Jit Poh, 19 October, 1938.

${ }^{56}$ Mak Lau Fong, The Dynamics of Chinese Dialect Groups in Early Malaya, Singapore: Society of Asian Studies, 1995, pp.165-173.

${ }^{57}$ Annual Report on the Social and Economic Progress of the People of Selangor, 1921, pp.31-33.

${ }^{58}$ Annual Report of the Secretary for Chinese Affairs of Selangor, 1921, pp.65-66.

${ }^{59}$ Yen Ching Hwang, Class Structure and Social Mobility in the Chinese community in Singapore and Malaya, 1800-1911, Singapore: Oxford University Press, 1986, pp.143-147.

${ }^{60}$ Tan Chee Beng, Chinese Overseas: Comparative Cultural Issues, Hong Kong: Hong Kong University Press, 2004, p.69.

\section{References}

\section{Primary Sources}


The National Archives, Kew Garden London

Colonial office: CO 273, CO717.

Federation Office: FO 628, FO 931, FCO 141.

\section{Arkib Negara Malaysia, Kuala Lumpur}

'Towkay Loke Yew's Ulu Bernam Concession', File No. 1957/010382,

'Letter of District Officer, Ulu Selangor, to the Resident of Selangor, 11 December 1901', File No: 1957/0100660

'Letter of District Officer, Ulu Selangor, to the Secretary to Resident, Selangor, $17^{\text {th }}$ February 1908', File No.1957/01000790,1957/0215211,1957/0162060.

\section{National Archives of Singapore}

File No. ROC 312. NAS. 'Kwong Yik Banking Co. Ltd.'

\section{Academia Historica Taiwan}

The Archive of the Ministry of Foreign Affairs, 1927-1941, 35/5.1-5.5.

\section{Government and Census Reports}

1.Nathan, J.E. The Census of British Malaya, London: Waterloo, 1922.

2.Del Tufo, M.V. eds, Malaya comprising the Federation of Malaya and the Colony of Singapore: A Report on the 1947 Census of Population, London: Crown Agents for the Colonies, 1949.

3.Fell, H. 1957. Population of the Federation of Malaya, Report No.14, Kuala Lumpur: Department of Statistics, 1957.

4.Annual Report of the Secretary for Chinese Affairs, Kuala Lumpur: Federated Malay States Government Press, 1921-1938.

5.Annual Report on the Social and Economic Progress of the People of Selangor, Kuala Lumpur: Federated Malay States Government Press,1921-1941.

\section{News Papers and Magazines}

1. Selangor Kwong Siew Association: Seventieth Anniversary Commemoration Magazine of Selangor Kwong Siew Hui Kuan, 1957.

2. Selangor Hokkien Association: 100 Anniversary Commemoration Magazine of the Selangor Hokkien Association, 1985.

3. Selangor Fui Chiu Association: 140 Anniversary Magazine of the Fui Chiu Association, 2004.

4. Selangor Kwangtung Association: 80 Anniversary Magazines of the Selangor Kwangtung Association, 2009.

5. Selangor Kwong Siew Association :130 Anniversary Magazine of the Selangor Kwong Siew Association, 2017.

6. Sin Chew Jit Poh ,1937-1938.

7. Yik Khuan Pao,1919-1925.

8. New Yik Khuan Pao, 1935-1936.

9. The Malay Mails, 1891-1904, 1906, 1911-1912, 1916-1918.

10. Nan Yang Siang Pau, 1923-1939.

11. Shanghuihuixun 2000 (Magazine of the Selangor Chinese Chamber of Commerce 2000).

\section{Secondary Sources}

\section{Books}

1.Mak Lau Fong, The Dynamics of Chinese Dialect Groups in Early Malaya, Singapore: Singapore Society of Asian Studies, 1995. 
2.Mak Lau Fong, The Sociology of Secret Societies; A Study of Chinese Secret Societies in Singapore and Colonial Malaya. Kuala Lumpur: Oxford University Press, 1981.

3.Tan Chee Beng, Chinese Overseas: Comparative Cultural Issues. Hong Kong: Hong Kong University Press, 2002

4. Tan Miau Ing, Tun Sir Henry Lee Hau Shik. Ahli Perniahaan dan Tokoh Politik (Tun Sir, Henry Lee Hau Shik, A Business member and Political Character), Kuala Lumpur: Penerbit Universiti Malaya, (University of Malaya Press), 2018.

5. William Tai Yuen, Chinese Capitalism in Colonial Malaya: 1900-1941, Bangi: Penerbit Universiti Kebangsaan Malaysia (UKM Press), 2013.

6. Yen Ching Hwang, Class Structure and Social Mobility in the Chinese community in Singapore and Malaya, 1800-1911, Adelaide: History Department, University of Adelaide, 1983.

7. Yong Chin Fatt, Chinese Leadership and power in Colonial Singapore and Malaya. Singapore: Time Academic Press, 1991.

8. Yong Chin Fatt, and R.B. Mckenna, The Kuomintang Movement in British Malaya, 19121949, Singapore: Singapore University Press, 1990.

9. Victor Purcell, The Chinese in Malaya, London: Oxford University Press, 1948.

10. Emily Sadka, The Protected Malay States, Kuala Lumpur: University of Malaya Press, 1968.

11. Wang Gung Wu, Do Not Leave Home: Migration and the Chinese, Singapore: Eastern University Press, 2001

12. Lee Kam Hing \& Chow Mun Seong, Biographical Dictionary of The Chinese In Malaysia, Petaling Jaya: Pelanduk Publications, 1997.

13. Lee Ting Hui, Chinese School in Peninsula Malaysia: The Struggle for Survival. Singapore: Institute of Southeast Asian Studies, 2011.

14. Blythe, Wilfred, The Impact of Chinese Secret Societies in Malaya: A Historical Study. London: Oxford University Press, 1969.

15.Hara Fujio, Malayan Chinese and China: Study on the Conversion in Identity Consciousness of Malayan Chinese. Singapore: NUS Press, 2017.

16. Ser Wui Hiong, (eds), Moving Mountains, Kuala Lumpur: Centre for Malaysian Chinese Studies, 2013.

17. J.M. Gullick, Kuala Lumpur, 1880-1895, Singapore: Malayan Branch of the Royal Asiatic Society, 1955.

18.Wang Fu Bing, Ma lai ya hua ren de fang yan qun fen bu yu zhi ye jie gou, 1800-1911( The Chinese Dialect Groups' Distribution and Occupational Structure in Malaya, 18001911), Kunming: Yunnan Arts Press,2012,

\section{Journals and Articles}

1.Blythe. WL, "Historical Sketch of Chinese labour in Malaya." JMBRAS 20, No.1. (141(1947): pp.64-114.

2.Chan King Nui \& Chan Chin Cheung, "A Short Biographical Record of Chan Wing, an Early Pioneer of Malaya, 1873-1947." JMBRAS 69, No. Part.1. (1996): pp.112-117.

3.Chin Yong Fong, "The Chinese Protectorate of Selangor 1896-1906." Malaysia in History 15 (1972): pp.30-42.

4.Glover, Patricia, "Low Malayan Tin Quota Leads to Chinese Unemployment". Far Eastern Survey 8, No. 13 (1939): p.154.

5.Hara Fujio, "An Alternative View of Tun Sir H. S. Lee; The Anti-Japanese Movement and His Dedication to China." Journal of Asia-Pacific Studies, No.20 (2013): pp.53-63.

6.Lee, Sharon M, "Female Immigrants and Labour in Colonial Malaya: 1860-1947." International Migration Review 23, No.2 (1989): pp.309-331.

7.Stenphenie, Chung Po-Yin.2002.' Surviving Economic Crisis in Southeast Asia and 
southern China: The History of Eu Yan Sang Business Conglomerate in Penang, Singapore, and Hong Kong', Modern Asian Studies, vol.36, no 3, pp. 579-617.

8.Tan Miau Ing, The Formation of the Pre-War Leaders of Malaya: H.S. Lee as a Case Study, Journal of Malaysian Chinese Study, Kuala Lumpur: Centre for Malaysian Chinese Studies, 17. (2014).

9.Chin Chong Foh, "Cong Hua Qiao, Hua Ren Dao Malaiya Ren (From Chinese Oversea sojourner, Malayan Chinese to Malayan Subject, The Life Journey With Role Identity Transformation, Tun Leong Yew Koh): Centennial Tracing: A study of Historical Personalities in Malaysia and Singapore, edited by Ho khai Leong, Petaling Jaya: Centre for Chinese Studies Research, University of Tunku Abdul Rahman, 2013.

10.All Malaya Chinese Miner Association, eds, The Development and Decline of Malaysian Chinese Tin Industry, Ipoh: All—Malaya Chinese Miner Association, 2002.

11.Voon Phin Keong, Ma Lai Xi Ya kejiazuqunde ren kou, Sheng Ji ji Wen Hua Tan Jiu [ The study of the Hakkas' Census, type of life and Culture]. pp.155-172.The Conference Papers Collections from The $30^{\text {th }}$ World Hakka Conference, ed by Dr Lai kwan Fook. Kuala Lumpur: The Federation of Hakka Associations of Malaysia.

12 Francis Lok Kok Wah, Beyond the Tin Mines: Coolies, Squatters, and New Villagers in the Kinta Valley, Malaysia, 1880-1980. Kuala Lumpur: Oxford University. 1988.

\section{Thesis and Dissertations}

1. Chow Mun Seong, 1992. 'Sejarah Komuniti Pelombong Timah Cina di Negeri Selangor, 1874-1920' [ A History of the Chinese Tin Mining Community in Selangor, 1874-1920], M.A. Dissertation, History Department, University of Malaya.

2. Koh Keng Wei, Eu Tong Sen: a case study in business expansion. M.A. Dissertation. 2000, Faculty of Arts, National University of Singapore.

3. Fairisa Binti Othman, "Sumbangan Orang Cina Di Tanah Melaya Kepada Negara Cina: 1880 - 1941(The donation from Malaysian Chinese to Mainland China: 1880 - 1941)", M.A. Dissertation, History Department, University of Malaya, 2004.

4. Stephen Leong Mun Yoon, "Source, Agencies and Manifestations of Overseas Chinese Nationalism in Malaya, 1937-1941.” Ph. D Thesis, University of California, 1976.

5. Tan Gaik Yeong, 'British Economic Policy towards the Malays in the Federated Malays in the Federated Malay States 1921-1934." M.A. Dissertation, History Department, University of Malaya, 1969.

6. Wan Ming Sing, "The History of the Organizations of the Chinese community in Selangor with Particular Reference to Problems of Leadership, 1857-1962." M.A. Dissertation, History Department, University of Malaya, 1967.

7. Tso Wen Yi, Min Guo Chu Qi De Guo Yu Yun Dong, (The promotion of National language movement on the early period of the Republic of China), M.A. Dissertation, Taiwan: National Culture University, 1973. 